() С. Б. Фіялка, к.н. із соц. ком., КП। ім. Ігоря Сікорського, Київ, Україна

\title{
НОВИНИ СЕПАРАТИСТСЬКИХ ІНТЕРНЕТ-МЕДІА В ІНФОРМАЦІЙНІЙ ВІЙНІ ПРОТИ УКРАЇНИ
}

Досліджено медійну політику терористичних угруповань, яка стала одним з інструментів ведення гібридної війни в Україні. Виділено тематичні групи новин, що становлять звичний порядок денний сепаратистських новинних сайтів: гіперболізація економічних, політичних, соціальних та інших негараздів в Україні; “криваві злочини" українських “карателів"; деморалізація Збройних сил України (суїциди, низький рівень військової дисципліни); “досягнення» самопроголошених республік, “подвиги» ополченців; повідомлення про успіхи Росії в економіці, зовнішній політиці тощо; критика США; негатив про ставлення в Україні до бійців АТО та волонтерів; критика ставлення в Україні до внутрішніх переселенців, російської мови. Обґрунтовано необхідність та запропоновано напрями інформаційно-роз'яснювальної роботи серед населення, виховних, просвітницьких заходів,

які б об'єднували українське суспільство навколо ідеї української державності.

Ключові слова: інформаційна війна; новини; маніпуляція; медіа; гіперболізація; українське суспільство; українська державність.

\section{Постановка проблеми}

Десятиліттями Російська Федерація веде антиукраїнську інформаційну кампанію, в основі якої - поширення недостовірної, неповної, упередженої інформації про Україну, маніпулювання суспільною свідомістю як громадян України, так і інших держав, пропаганда війни, національної та релігійної ворожнечі, заперечення права українців на державність. При цьому активно використовуються аналітичні центри («Русский мир»), багатомовні телеканали («RussiaToday», «РИА
Новости»), новинні агенції («Sputnik»), Російська православна церква, соціальні мережі. В умовах війни на Донеччині та Луганщині активно працюють сепаратистські сайти, які, відповідно обираючи та емоційно забарвлюючи новини, формують у своєї аудиторії (передусім мешканців непідконтрольних територій) спотворену картину світу, впливають на психічний стан споживачів інформації, їхню поведінку.

Сепаратистські новинні сайти дотримуються спільних пріоритетів у доборі тем для висвітлення,

(ㄷ) $2017 \mathrm{p}$. 
тобто одні події набувають більш широкого розголосу, аніж інші, та сприймаються аудиторією як більш актуальні, хоча вони далеко не завжди відповідають реальним інтересам самої аудиторії. Крім того, ці сайти схильні продукувати численні фейкові новини, привертаючи до них надмірну увагу аудиторії, роздмухувати абсолютно штучні й неіснуючі проблеми. Журналісти сепаратистських медіа підкреслено вибірково ставляться до подій, що відбуваються, залишаючи при цьому для трактування лише ті з них, які вигідні для виправдання політики влади самопроголошених республік. За їхнім посередництвом інформація перетворилася на небезпечну зброю, яка $€$ дешевою, універсальною й легко долає кордони [1, С. 7]. Сайти сепаратистів відверто й агресивно навіюють мешканцям тимчасово окупованих територій російський політичний наратив «русский мир», «російські цінності», «російська душа» [2, С. 92], дедалі активніше вдаючись з використанням сучасних технологій до методів інформаційного впливу, поширених ще за часів холодної війни [3]. При цьому більшість громадян неконтрольованих українською владою територій психологічно не готові адекватно протидіяти пропаганді, замаскованій під «альтернативну думку» [4, С. 121-132].

\section{Аналіз попередніх досліджень}

Серед дослідників інформаційної агресії варто виділити праці $€$. Магди. У книзі «Гібридна війна: вижити і перемогти» наголошується на ключовій ролі інформаційного складника гібридної загрози [5]. В іншій праці науковець вирізняє широкий спектр методів гібридної війни, зокрема: «криве дзеркало» (перекручування фактів); «спекуляції на історії» (використання дискусійних моментів українсько-російської історії); «заперечення очевидного» (створення видимості відсутності агресії); «килимове бомбардування дезінформацією» (поширення панічних настроїв, що має призвести до дестабілізації ситуації всередині країни); «перетягування Заходу» (намагання створити проросійську коаліцію, лобіювання інтересів Росії європейськими політиками, формування позитивного образу Росії в Європі); «показна миротворчість» (створення ілюзії, що Росія не причетна до конфлікту); «гримаси демократії» (нагнітання внутрішньополітичного напруження в Україні); «економічні лещата» (економічна залежність України від Росії); «фактор газу для Європи» (стратегія звинувачення України у проблемах із зимовими поставками газу [6]. Специфіці та особливостям інформаційного протистояння присвячено праці В. Горбуліна «Гібридна війна» як ключовий інструмент російської геостратегії реваншу» [7], В. Черниш «що відбувається на Сході України. Ще раз про термінологію» [8], Л. Смоли «Аспекти нелінійної війни в контексті українсько-російського конфлікту на Донбасі» [9] тощо.

\section{Мета роботи}

Виділити тематичні групи новин, які становлять звичний порядок денний сепаратистських 
новинних сайтів, задля з'ясування напрямів інформаційного впливу на мешканців непідконтрольних територій та розроблення інструментарію протидії цим впливам.

\section{Результати проведених досліджень}

Як зазначає Р. Харріс, «масмедіа здатні структурувати когнітивні можливості аудиторії і вносити зміни в наявні когнітивні можливості» [10]. Тобто медії вказують аудиторії, про що думати [11]. 3 огляду на це, 3 початком війни на Донбасі та Луганщині запущено чимало вебресурсів, які імітують інформаційні агентства, новинні сайти, зокрема: «Русская весна» (rusvesna.su), Інформаційне агентство «Новороссия» (novorosinform.org), Інформаційне агентство «Антифашист» (http://antifashist.com), «Новости Донецкой Республики» (www.dnr-news.com). Саме вони провадять медійну політику терористичних угруповань та стали одним із засобів ведення воєнних дій. Основною метою таких проектів $€$ створення системи інформаційного впливу на мешканців неконтрольованих українською владою територій як плацдарму для проведення інформаційно-психологічних операцій.

Із часу свого заснування на початку 2014 р. і до листопада 2016 р. зазначені сайти розмістили відповідно приблизно 62000, 30000, 13600, 12000 новин. Дослідження новин було проведено за весь період; для забезпечення відносної достовірності його результатів було зроблено вибірку: кожна двадцята новина з кожного ресурсу. Усього було проаналізовано заголовки 5800 новин. Виявлено, що за тематико-емоційним навантаженням переважають позитивні новини, які становлять $59 \%$ контенту (рис. 1). Це новини, які викликають у людей позитивні, радісні емоції. 18 \% з них - новини про «досягнення» нової влади в економічній та соціальній сферах. Однак до позитивних новин у контексті аудиторії сепаратистських інтернет-ЗМК можна віднести також новини про загибель українських військових, новини, які сповіщають про економічні, політичні й соціальні негаразди в Україні (зростання тарифів, інфляція, провал тих чи інших реформ, дестабілізація політичної ситуації тощо). I саме таких псевдопозитивних новин значно більше $-41 \%$. Проте, з огляду на обмеженість ресурсів для проведення масштабного інтерв'ю, не варто робити однозначних висновків стосовно усього населення тимчасово окупованих територій, що воно сприймає такі новини тільки як позитивні.

Негативні новини становлять 34 \%. Це новини, які викликають сум, агресію, роздратування, новини про загибель «ополченців», жертви серед мирного населення, руйнування. На нейтральні новини, які не можуть викликати яскраво виражені емоції, припадає лише 7 \%.

Таке співвідношення емоційно забарвлених новин свідчить про незбалансованість подання інформації, особливо щодо подання новин про кризу в Україні, що може створювати ефект сугестії у глядача стосовно того, що на територіях самопроголошених республік усе набагато краще. 
Поглиблений моніторинг інформаційних «продуктів» кремлівської пропагандистської машини дозволяє виокремити тематику меседжів, які намагаються нав'язати «реципієнтам» інформаційно-психологічної обробки українським громадянам, які проживають на тимчасово окупованих територіях.

Розподіл новин сепаратистських сайтів за тематикою наведено на рис. 2.

Проаналізуємо ці тематичні блоки за заголовками новин.

Гіперболізація економічних, політичних, соціальних та інших негараздів в Україні. Сепаратистські сайти активно тиражують повідомлення, які змальовують кризові явища в Україні, часто з нотами сарказму. Так, однозначно стверджується, що після Революції Гідності Україна скотилася в економічну прірву, наприклад: «Украина готовится заморозить саму себя» (http://rusvesna.su, 26.10.2016); «Бюджет Украины на 2017 год - нищета под диктатом МВФ» (http://rusvesna.su, 14.10.2016); «Число нищих на
Украине перевалило за 50 процентов» (http://rusvesna.su, 09. 10.2016); «Хроники евроинтеграции: украинцы переходят на просроченные продукты» (http:// antifashist.com, 20.10.2016); «Аутодафе от жизни в «цеевропе»: на Тернопольщине пенсионер сжег себя, не в состоянии прокормить сына-инвалида» (http:// antifashist.com, 25.07.2016); «Зерно гонят на экспорт, а для украинцев - хлебные карточки» ( http://antifashist.com, 06.03.2015); «Газ не по карману: украинцы перейдут на коников из кизяков» (http://antifashist. com, 02.05.2016); «На Украине ожидают рост цен из-за ухудшения торговых отношений с Россией» (novorosinform.org, 14.01. 2016); «Пенсионные «грабли» Украины» (https://novorosinform. org, 27.10.2016); «Украина: «успехи» колониальной экономики» (https://novorosinform.org, 11.07.2016); «Экономика Украины продолжит падение в результате самоизоляции от России» (https://novorosinform.org, 10.06.2016); «МВФ поставил

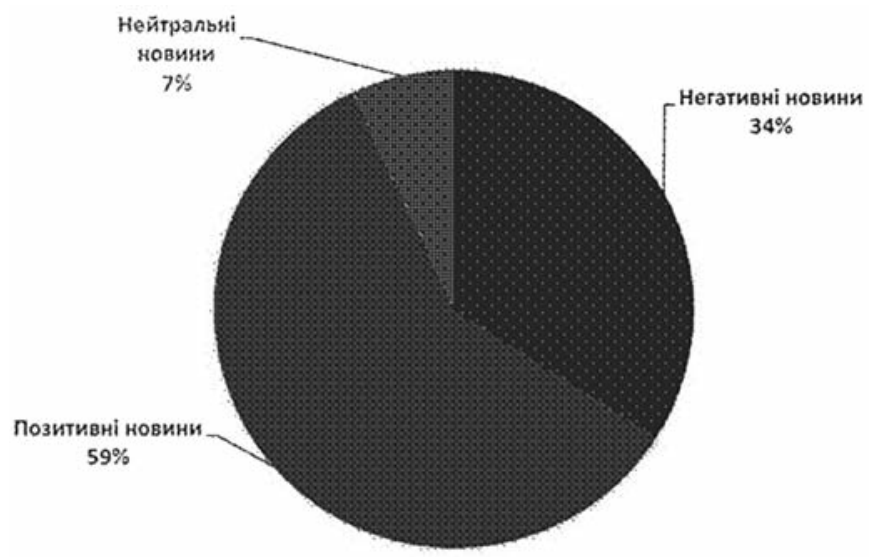

Рис. 1. Співвідношення контенту сепаратистських медіа за тематико-емоційним навантаженням 
Украину в ряд банановых республик» (https://novorosinform. org, 11.03.2016); «Голодомор2016: киевские пенсионеры в очередях за бесплатным супом» (http://rusvesna.su, 02.10.2016); «Гривна установила новый рекорд падения (https://novorosinform.org, 01.02.2016)».

Наголошується, що країна позбавлена військового потенціалу: «Украине скоро нечем будет воевать: Советские запасы заканчиваются, собственного производства нет» (https://novorosinform.org, 03.02.2015), а очікуваний усіма безвізовий режим ніколи не стане реальністю: «Вместо «безвиза» - «железный занавес»: украинцам начали закрывать выезд в Европу» (http://rusvesna.su, 03.11.2016). Тим часом українська влада сама не може впоратися з поточними проблемами й шукає допомоги зовні: «В Украине объявили о поисках иностранца, способного управлять оборонной промышленностью страны» (https://novorosinform. org, 22.08.2015), однак при цьому ця сама влада веде злочинну політику проти власного народу: «Украинские власти готовятся «отжимать» частную собственность» (https://novorosinform.org, 28.10.2016); «Победа Майдана: Минздрав Украины не будет помогать онкобольным» (http:// rusvesna.su, 08.11.2016); «Пушечное мясо на убой: режим отправляет на передовую 18-летних «контрактников» без снаряжения и без понятия, что такое автомат» (http://antifashist.com,

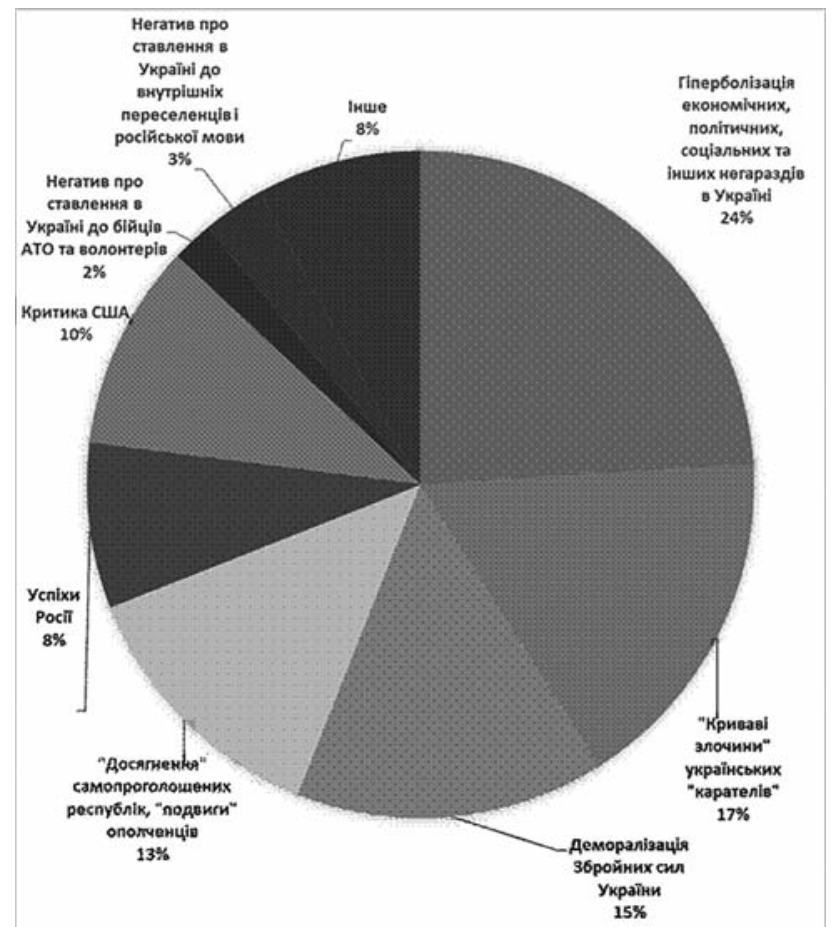

Рис. 2. Розподіл новин сепаратистських сайтів за тематикою 
26.10.2016). Апокаліптична картина доповнюється тим, що в Україні процвітає ніким не контрольована злочинність, а в суспільстві панує аморальність, наприклад: «Под Киевом 11 вооруженных «коллекторов» вышвырнули семью на улицу» (http:// rusvesna.su, 09.11.2016); «В квартире херсонского чиновника взорвали гранату» (http://rusvesna. su, 04.11.2016); «Типичная Украина: В Черкассах вор похитил игрушки из детсада» (http:// rusvesna.su, 13.10.2016); «Типичная Украина: На Львовщине школьники отравились водкой во время занятий» (http://rusvesna.su, 06.10.2016); “Сверкающие грани победившего достоинства: на Украине убивают и умирают за пакет крупы и сахара» (http:// antifashist.com, 01.11.2016); «Moбилизация по-галичански: на военкомов бросаются с топорами, спускают собак и матерят на чем свет стоит» (http://antifashist.com, 27.10.2016); «В Украине резко возрос уровень преступности: полиция способна охранять только геев» (http://antifashist.com, 18.06.2016); «Це Европа: в Одесской области пьяные судьи и прокуроры охотились на людей» (http://antifashist.com, 25.11.2014); «Украина не Европа: на Черниговщине обокрали международного наблюдателя из США» (http://antifashist.com, 27.10.2015); «Обычное дело на Украине: пьяный одессит пришел в бар с автоматом Калашникова» (https://novorosinform.org, 13.06.2016). Хaрактерно, що навіть відверто позитивні новини подаються як негатив: «Украине предписано учить язык хозяев» (http://antifashist.com, 18.11.2015).
«Криваві злочини» українських «карателів». На сепаратистських новинних сайтах формується негативний образ українських військових, які начебто руйнують житлові будинки та об'єкти інфраструктури, убивають жінок і дітей: «Боевик нацгвардии Украины зарезал прохожего в Мариуполе» (http://rusvesna.su, 08.11. 2016); «12 «одвичных лыцарив» 10 дней насиловали девочку на Донбассе пока жертва не умерла» (http://antifashist.com, 10.08. 2016); «ВСУ убили подростка на линии соприкосновения в ДНР» (novorosinform.org, 12.11.2016); «Украинские каратели 2,5 часа разгоняли очередь на КПП «Станица Луганская» с помощью пулеметов и гранатометов» (novorosinform.org, 11.11.2016); «Звериные нравы: нацгвардия растерзала семью из пяти человек» (http://antifashist.com. 22.09.2014); «В Мариуполе нацгвардия расстреляла двух подростков-велосипедистов » (http://antifashist.com, 22.09.2014); «Украинские оккупанты обстреляли окраины Донецка, Горловки и Ясиноватой» (novorosinform.org, 22.10.2016); «Украинские каратели обстреливают дома в Станице Луганской с целью обвинения в обстрелах ЛНР» (novorosinform.org, 20.10. 2016); «Герои АТО шлют на родину золотые коронки и цепочки, «снятые со зверей» (http://antifashist.com, 19.01.2015); "Освободители» убивают и грабят Донбасс: расстреляна пожилая семья» (http://antifashist.com, 24.12.2014); «Украинские диверсанты казнили ополченца и его беременную жену» (http://antifashist.com, 21.06.2015); "Kapa- 
тели отобрали награды у ветерана Великой Отечественной войны» (http://antifashist.com, 04.10.2014); «На Донбассе под гусеницами украинского танка погибла семейная пара» (novorosinform.org, 14.10.2016); «УКраина применяет на Донбассе запрещенные противопехотные мины» (novorosinform.org, 11.12. 2015); «Умерла ветеран, которую в День Победы облили зеленкой в Славянске» (www.dnr-news.com, 13.05.2016); «От рук украинского снайпера погибла еще одна женщина» (https://novorosinform. org, 28.08.2016); «Пушилин: украинские нацисты угрожали отравить воду в Донецке в случае освобождения Мариуполя» (https: //novorosinform.org, 02.07.2016); «Украинские военные избили на блок-посту мирного жителя «для профилактики» (https://novorosinform.org, 25.06.2016); «Горе 4-рех сирот после гибели отцаополченца» (https://novorosinform.org, 28.12.2015); «Минувшей ночью украинские каратели разбомбили детский сад в Горловке» (https://novorosinform.org, 01.08.2015); «Укры расстреляли в ДНР сиамских близнецов, калек-инвалидов» (https://novorosinform.org, 17.02.2015); «B результате обстрела Донецка ранен трехлетний мальчик» (https://novorosinform.org, 04. 02.2015); «Наблюдатель ОБСЕ: каратели бомбят исключительно по мирным целям» (20.07. 2014); «Беженка из Славянска вспоминает, как при ней казнили маленького сына и жену ополченца» (https://novorosinform.org, 13.07.2014); «Украинские каратели выгоняют семьи из домов и сами заселяются туда» (https: //novorosinform.org, 17.07.2016); «Украина торгует детьми из Донбасса» (https://novorosinform.org, 14.12.2015) тощо.

Деморалізація Збройних сил України. Сепаратистські новинні ресурси дедалі частіше змальовують українських військових аморальними, психічно хворими й нездатними воювати: «Свинья всегда грязь найдет: в Киеве голосят, что донбасские проститутки ведут против ВСУ ВИчи СПИД-террор» (http://antifashist.com, 19.09.2016); «ATO» штампует для Украины психопатов, калек и алкашей» (http:// antifashist.com, 06.11.2014); «3eленый змий» помог украинским военным лишиться дорогого армейского имущества» (novorosinform.org, 17.09.2016); «Да ты ведьма!»: солдат ВСУ, оставшись без оружия, сослался на потусторонние силы» (novorosinform.org, 13.09.2016); «В Артемовске пьяный волонтер «АТО» с Западной Украины покусал полицейского» (novorossinform. org, 03.01.2016); «За неделю силами ВСУ выведено из строя до 15 единиц собственной техники» (novorosinform.org, 05.09. 2016); «Варяг: Бойцы ВСУ меняют боеприпасы на водку» (novorosinform.org, 05.11.2015); «Пьяные бойцы ВСУ на «Урале» разнесли частное подворье в Николаеве» (www.dnr-news.com, 08.05.2016); «Под Дзержинском собутыльник убил бойца ВСУ и расчленил его тело» (www.dnr-news.com, 25. 06.2016); «ВСУшники ограбили волонтера, помогавшую им же» (https://novorosinform.org, 31.08. 2016); «Украинские срочники от безысходности обменивают личные вещи и ГСМ на алкоголь» 
(https://novorosinform.org, 23.06.2016); «Для поднятия боевого духа командование ВСУ санкционировало спаивание солдат» (https://novorosinform. org, 14.06.2016); «Большинство киевских силовиков имеют психические расстройства» (https:// novorosinform.org, 06.09.2015); «Украинские военные готовы обменивать оружие на продукты» (https://novorosinform.org, 23.10.2014).

Регулярно з'являються повідомлення про зростання небойових втрат серед особового складу: «ВСУ бьют рекорды по небоевым потерям: за истекшую неделю самообезвредились 100 боевиков» (http://antifashist.com, 04.11.2016); «Небоевые потери: ВСУ за неделю обезвредили себя на 55 боевиков» (http:// antifashist.com, 24.09.2016); «Heбоевые потери ВСУ на прошлой неделе превысили 90 человек» (novorosinform.org, 01.11.2016); «Пьяный украинский солдат расстрелял двух сослуживцев» (nоvorosinform.org, 18.10.2016); «Боевики ВСУ уничтожили «дружественным огнем» двух сослуживцев» (novorosinform.org, 17.10. 2016); «Под Львовом покончил с собой очередной участник карательной операции ВСУ» (novorosinform.org, 11.10.2016); «Суициды в рядах ВСУ продолжаютСя» (novorosinform.org, 13.09. 2016); «Ворошиловский стрелок: под Ровно солдат ВСУ уложил семерых сослуживцев выстрелом из гранатомета" (novorosinform.org, 10.09.2016); «Военкор о ВСУ: сами минируют, сами взрываются - будни украинских боевиков» (novorosinform. org, 07.09.2016); «Небоевые по- тери в Донбассе превышают боевые» (www.dnr-news.com, 26.01.2016); «59 силовиков ВСУ совершили суицид» (https://novorosinform.org, 13.06.2016).

Повідомляється також про численні випадки дезертирства: «Украинских военных за дезертирство отправляют в психбольницу» (http://antifashist.com, 27. 10.2016); «Официально: на сторону ополчения Донбасса перешли 8 тысяч украинских силовиков» (novorosinform.org, 21.10. 2016); «Очередная самоликвидация: в Киеве дезертир ВСУ подорвал себя гранатой» (http: //antifashist.com, 13.10.2016); «Эхо Иловайска: украинский карбат в полном составе дезертировал с поля боя и не прикрыл товарищей» (http://antifashist. com, 26.08.2015); «Дезертирство среди ВСУ становится нормой - бегут от войны» (novorosinform.org, 08.10.2016). Крім того, з'являються повідомлення про те, що українці більше не бажають захищати свою землю в російсько-українському конфлікті: «Небоевые увечья: бойцы ВСУ калечат себя, чтобы не участвовать в войне» (novorosinform.org; 07.10.2016); «Украинцы спасаются от призыва покупкой статуса священника» (https: //novorosinform.org. 30.01.2015).

«Досягнення» самопроголошених республік, «подвиги» ополченців. Виправдовуючи власну політику, влада самопроголошених республік усіляко демонструє позитивні зміни на тимчасово окупованих територіях: «Дыра забитая»: в ДНР на зависть «европеизированной» Украине полный порядок с вакцинацией» (http:// antifashist.com, 03.11.2016); «Ужа- 
сы «оккупации»: в Луганске массово и бесплатно всем нуждающимся меняют старые окна на стеклопакеты» (http://antifashist. com, 10.09.2016); «Ученые ДНР разработают для медиков уникальный аппарат диагностики послеоперационных осложнений, не имеющий аналогов в мире» (http://antifashist.com, 12.09.2016); «На границе России и ЛНР создадут «территорию опережающего развития» (https://novorosinform.org, 02.02.2016).

Успіхи Росії в економіці, зовнішній політиці тощо. Сепаратистські новинні сайти нав'язують ідею про те, що Росія найрозвинутіша й найцивілізованіша держава у світі: «Россия ставит целую серию рекордов в сельском хозяйстве» (http://rusvesna.su, 21.10.2016); «В России увеличен прожиточный минимум» (https://novorosinform.org, 08.09.2016); «Медведев: в каждой российской семье есть автомобиль» (https://novorosinform.org, 10.09.2016); «Конец гегемонии США: Армия и флот России становятся основними стабилизирующими силами мировой политики» (rusvesna.su, 22.10.2016); «В Польше посоветовали нищей Украине даже не мечтать о развале куда более богатой России» (http://antifashist.com, 07.11.2016).

Критика США. За традицією прокремлівських медіа сайти самопроголошених республік активно звинувачують США у всіх загальносвітових і локальних бідах: «Госдума предполагает, что штамм гриппа создали в лаборатории США на Украине» (novorosinform.org, 27.01.2016); «Мир ожидает «век агрессии
США» (http://rusvesna.su, 29.10. 2016); «Конфликт в Донбассе дело рук США» (http://rusvesna.su, 24.10.2016); «Беспилотник США убил 13 мирных жителей» (http://rusvesna.su, 28.09. 2016); «Чего добиваются США и зачем провоцируют Россию в Сирии» (http://rusvesna.su, 30. 09.2016); «Множество жителей Сирии погибло от авиаударов США, - зампостпреда России в OOH» (http://rusvesna.su, 03. 08.2016); «США - самая большая угроза для Латинской Америки» (http://rusvesna.su, 25.06. 2015).

Негатив про ставлення в Україні до бійців АТО та волонтерів. Традиційний сценарій прокремлівської пропаганди - розповіді про бійців, які воювали за Україну, а тепер лежать у госпіталях без рук і без ніг і нікому не потрібні, тим часом їхні сім'ї через телебачення та інтернет збирають кошти на лікування. При цьому інвалідові ще треба доводити свою інвалідність та щороку її підтверджувати. Активно тиражуються повідомлення про зневагу до воїнів АТО як влади, так і пересічних українців: «Какие «герои», такие и награды: «ветерану АТО» выдали ржавую и поломанную медаль» (http:// rusvesna.su, 20.10.2016); «Куда ты это прятать будешь, когда наши придут?» - водитель маршрутки унизил боевика «АТО» (http://rusvesna.su, 13.10.2016); «В благодарность за «освобождение»: жители Дзержинска уничтожили памятник «героям ATO» (http://antifashist.com, 11. 11.2016); «Сидевших и участников АТО не беспокоить»: у харьковских работодателей расширили 
список неугодных соискателей» (http://antifashist.com, 09.11.2016); «В Одессе героев «АТО» хоронят как хирургические отходы» (http: //antifashist.com, 25.01.2015); «Нет тела - нет дела: Украина не признает погибшими не вернувшихся с Донбасса солдат» (http://antifashist.com, 25.02.2015); «Украинских военных кормят гнильём и поят из использованных одноразовых стаканчиков» (http://antifashist.com, 14.09.2015); «Кровь и смерть не для всех: киевские денежные мешки смеются над учасниками ATO» (http: //antifashist.com, 15.02.2016); «Уволенные в запас украинские военные вернутся домой с пустыми карманами» (novorosinform.org, 04.10.2016); «Офицеры украинской хунты торгуют солдатскими пайками» (novorosinform.org, 11.08.2014); «Солдат ВСУ записывают в самоубийцы, чтобы не выплачивать компенсацию» (novorosinform. org, 24.10.2014); «На Украине методично «убираются» волонтеры «АТО»: один повешен, от другого остались тапки, третью преследуют» (https://novorosinform.org, 22.8.2016).

Негатив про ставлення в $У_{K-}$ раїні до внутрішніх переселенців і російської мови. Традиційно нав'язується міф про полярність населення України - своєрідний уявний поділ населення на групи за мовно-етнічною та ідеологічною орієнтацією. Такий поділ вигадано для спекуляцій на тему розбіжностей у світогляді українців різних регіонів. Найяскравіше цей міф реалізовано в протиставленні «українська мова - російська мова», адже мововжиток пов'язують 3 куль- турними вподобаннями й загалом зі світоглядними цінностями: «На Галичине школьник изрезал учительницу ножом за то, что заставляла изучать русский язык» (http://antifashist.com, 17. 10.2016); «Продавщицу из Черкасс, отказавшуюся «обслуживать» патриотов на мове, выгнали с работы» (http://antifashist. com, 04.082016); «Мы закрыли русскоязычные классы в сотнях школ, - «гауляйтер Донецкой области» о насильной украинизации оккупированного Донбасca» (http://rusvesna.su, 21.09. 2016); «Язык твой - враг мой: как Украина борется с русским» (http://rusvesna.su, 01.09.2016); «В Киеве хотят запретить русский язык» (http://rusvesna.su, 19.03.2016); «Власти начинают насильственную украинизацию оккупированных районов ДНР» (http://rusvesna.su, 21.09.2015).

у цьому контексті доречно зауважити, що навіть деякі українські політичні партії визнають поляризацію населення, активно наголошуючи напередодні парламентських виборів на україномовності української України: «Чия земля? Чия мова?» (3 телереклами ВО Свобода»), «Українці за нашу Україну» (політична реклама «Нашої України», «неукраїнська Україна» (з реклами «Батьківщини»).

Зачіпаючи тематику переселенців, констатуємо, що, тікаючи від війни, близько 1,5 мільйона мешканців Донецької й Луганської областей вирушили до сусідньої Росії чи «на велику Україну» залежно від політичних уподобань та фінансових можливостей. Сепаратистськими медіа формується уявлення про нега- 
тивне ставлення до переселенців зі Сходу: поширюються численні публікації про ворожу позицію щодо переселенців, про те, що українці не хочуть здавати їм житло; а роботодавці не бажають брати їх на роботу: «Киевские волонтеры собирают вещи для переселенцев с Донбасса у помойки» (http://antifashist.com, 26.11.2015); «Во Львове готовятся поставить под ружье переселенцев из зоны так называемой ATO» (https: //novorosinform, 31.07.2014).

Серед решти новин варто звернути увагу на меседжі щодо сепаратистських настроїв в Україні: «Одесса увешана листовками, провозглашающими необходимость ухода из Украины к Новороссии» (http://antifashist. com, 25.05.2016); щодо порушення Україною норм міжнародного права: «Украинские силовики активно препятствуют проверкам СММ ОБСЕ, обстреливая наблюдательную аппаратуру» (novorosinform.org, 27.09.2016); щодо підтримки «Новоросії» у світі: «В Дублине состоялся митинг в защиту Новороссии от геноцида» (http://antifashist.com, 04. 08.2014) та непідтримки України: «Никто, кроме ботов: «поддержку всего мира» Украине обеспечивают десятки тысяч компьютерных роботов с британских серверов» (http://antifashist.com, 04.11.2016). Тиражуються відверто фейкові новини типу: «Украинки требуют разрешения платить за ЖКХ натурой» (http:// antifashist.com, 05.10.2016); «B Киеве откроют кабинки для секca» (http://antifashist.com, 19. 08.2015); «В Украине собираются учить детей по программе
Гитлерюгенда» (http://antifashist. com, 10.05.2016); «В Киеве признали, что ИГИЛ - союзник Украины» (novorosinform.org, 17.11. 2015); «Пьяный Петр Порошенко рвался поговорить с Владимиром Путиным» (novorosinform.org, 05.09.2015); «В Киеве заявили, что Канаду создали украинские колонисты» (www. dnr-news.com, 11.07.2016). Крім того, наявні окремі повідомлення мотиваційного характеру щодо вступу в лави «ополчення»: «Молодые юноши на ряду с опытными бойцами активно вступают в ряды ополчения» (https://novorosinform.org, 10.02.2015); «Пенсионеры ЛНР просят отправить их на передовую» (https://novorosinform.org, 10.02.2015).

Якщо аналізувати тематичні групи новин з погляду дотримання журналістських стандартів, то очевидним $€$ порушення балансу думок, оскільки точки зору опонентів, у тому числі тих, хто став об'єктом журналістської критики, не подано. Порушується також право споживача інформації на її достовірність, оскільки журналісти сепаратистських медіа часто наводять факти непевного походження, поширюють спотворену, а подеколи й відверто фейкову інформація. Не дотримуються в аналізованих медіа і принципів відокремлення фактів від коментарів.

Тим часом завдання навести лад в інформаційному середовищі стоїть перед Міністерством інформаційної політики. Створене 2 грудня 2014 р. Міністерство інформаційної політики України на сьогодні $€$ необхідним 
елементом формування стратегії національної безпеки України. Його діяльність спрямована на те, щоб розробити інструменти для протидії російській інформаційній війні. Зокрема, за ініціативою Міністерства почала діяти «українська інформаційна армія». Команда волонтерів запустила TrolleyBust - сервіс з відстежування та блокування інтернет-тролів та інших джерел антиукраїнської інформації. Свою діяльність волонтери порівнюють з партизанською війною в інформаційному просторі.

\section{Висновки}

Задля досягнення успіху в «битві за мізки» було припинено доступ громадян тимчасово окупованих територій до альтернативних новин і аналітики. Так відбулося одурманювання мільйонів людей, які звикли некритично споживати медіапродукти. Сепаратистські сайти мають на меті орієнтувати громадську думку в бажаному для самопроголошеної влади напрямі. Діяльність сепаратистських медіа становить значну небезпеку, оскільки вони здатні впливати не лише на свідомість, але й на поведінку реципієнтів. Ми маємо справу з випадками, коли після контакту із сепаратистськими медіа в людини спалахує ненависть до своєї країни, адже ЗМК подають події так, щоб жителі тимчасово окупованих територій та Росії вірили, що конфлікт організований Україною, а українські «карателі» воюють проти власного народу.

Ступінь впливу розглянутих повідомлень значною мірою залежить від характеристик реци- пієнта. Безперечно, не всі споживачі інформації під впливом певного медійного матеріалу активно змінюють свої ціннісні орієнтири, багато з них володіють цілісним світоглядом, що гарантує психологічну й ідеологічну стійкість в умовах постійної інформаційної війни. Найбільш сильний вплив аналізовані повідомлення мають на пасивну аудиторію, схильну до некритичного сприйняття інформації. Різні реакції на одні й ті самі комунікаційні подразники значною мірою зумовлені життєвим досвідом, рівнем освіти, індивідуальними психологічними особливостями. Ефективність і сила інформаційного впливу залежать від прийнятого в соціумі ступеня довіри до мас-медійної інформації, стійкості власної позиції реципієнта стосовно тих чи інших суспільних явищ, подій.

Тож в Україні назріла потреба у формуванні медіапросьюмеризму, тобто компетентного медіаспоживання, яке виявляється в здатності аналітично вибирати, перевіряти, порівнювати, оцінювати й декодувати медіапродукти. Слід запровадити комплексну програму захисту громадян країни від деструктивних впливів інформаційної війни, забезпечити масову просвіту населення. Потрібно навчати медіаспоживачів фільтрувати інформацію та перевіряти її, проглядати хоча б кілька джерел, а не хапатися за один канал або сайт, відстежувати свій психоемоційний стан після контакту з медіа, адже показником вторгнення психічного вірусу $є$ : підвищена емоційність, немотивована агресія, роздратування, 
навала деструктивних думок або апатія, депресія, пригніченість. Необхідно проводити семінари 3 інформаційної грамотності серед різних цільових груп: вимушені переселенці з Донецької та Луганської областей, поранені військові в госпіталі, учасники ATO, лікарі, педагоги, студенти вишів, школярі, пенсіонери. Ко- жен громадянин має опанувати механізми критичного осмислення й коригування інформації, уміннями інтерпретувати, аналізувати та оцінювати медіатексти, розуміти їхню суть, адресну спрямованість, мету, викривати приховане значення та шкідливий вплив, критично ставитися до постів, у яких наявні панічні настрої.

\section{Список використаної літератури}

1. Darczewska, J. Theanatomy of Russian information warfare. The Crimeanoperation, a casestudy / J. Darczewska // Point of view. - 2014. - No. 42. - P. 5-37.

2. Levin Jaitner, M. Russian Information Warfare : Lessons from Ukraine / M. Levin Jaitner. - Tallin : CCDCOE. - P. 92.

3. Meister, S. The Roots and Instruments of Russia's Disinformation Campaign [Electronic resource] / S. Meister. - Mode of access : http://www. transatlanticacademy.org/sites/default/files/publications/Meister_IsolationPro poganda_Apr16_web_1.pdf10 (Retrieved October 11, 2016).

4. Aro, J. The cyberspace war: propaganda and trolling as warfare tool / J. Aro // EuropeanView. - 2016. - Vol. 15, Issue 1. - pp. 121-132.

5. Магда Є. Гібридна війна : вижити і перемогти / Є. Магда. - Харків : Віват. -320 с.

6. Магда Є. Виклики гібридної війни : інформаційний вимір / Є. Магда // Наук. зап. Ін-ту законодавства Верховної Ради України. - 2014. - № 5. C. $138-142$.

7. «Гібридна війна» як ключовий інструмент російської геостратегії реваншу / В. П. Горбулін // Стратегічні пріоритети. - Київ : НІСД, 2014. № 4. - C. 5-12.

8. Черниш В. Що відбувається на Сході України. Ще раз про термінологію [Електронний ресурс] / В. Черниш. - Режим доступу : http://osvita.mediasapiens.ua/media_law/law/scho_vidbuvaetsya_na_skhodi_ukraini_sch e_raz_pro_terminologiyu (дата звернення: 11.10.2016).

9. Смола Л. Є. Аспекти нелінійної війни в контексті українсько-російського конфлікту на Донбасі / Л. Є. Смола // Наук. часоп. НПУ імені М. П. Драгоманова. Серія 22 : Політичні науки та методика викладання соціально-політичних дисциплін. - 2015. - Вип. 16. - С. 74-78.

10. Харрис, Р. Психология массовых коммуникаций. - 4-е изд., междунар. - СПб : Прайм-Еврознак, 2003. - 445 с.

11. Cohen, B. The Pressand Foreign Policy / B. Cohen. - Princeton : Princeton University Press, 1963. - 288 p.

\section{References}

1. Darczewska, J. (2014). The anatomy of Russian information warfare. The Crimean operation, a case study. Journal of Point of view, 42, 5-37 [in English].

2. Levin Jaitner, M. (2015). Russian Information Warfare: Lessons from Ukraine. Tallin, Estonia: CCDCOE [in English].

3. Meister, S. (2016). The Roots and Instruments of Russia's Disinformation Campaign. Retrieved October 11, 2016, from http://www.transatlanticacademy.org/sites/default/files/publications/Meister_IsolationPropoganda_Apr16_w eb_1.pdf10 [in English]. 
4. Aro, J. (2016). The cyberspace war: propaganda and trolling as warfare tool. Journal of European View, 15(1), 121-132 [in English].

5. Mahda, Ye. (2015). Hibrydna viyna: vyzhyty i peremohty [Hybrid Warfare: survive and win]. Kharkiv, Ukraine: Vivat [in Ukrainian].

6. Mahda, Ye. (2014). Vyklyky hibrydnoyi viyny: informatsiynyy vymir [Challenges of Hybrid Warfare: information aspect]. Journal of Naukovi zapysky Instytutu zakonodavstva Verkhovnoyi Rady Ukrayiny - Scientific notes the Institute of Legislation of Verkhovna Rada of Ukraine, 5, 138-142 [in Ukrainian].

7. Horbulin, V. (2014). 'Hibrydna viina' yak klyuchovyi instrument rosiiskoi heostratehii revanshu [Hybrid warfare as a key instrument of Russian revenge geostrategy]. Journal of Stratehichni priorytety, 4, 5-12 [in Ukrainian].

8. Chernysh, V. (2014). Shcho vidbuvaietsia na Skhodi Ukrainy. Shche raz pro terminolohiiu [What is happening in eastern Ukraine. Once again on terminology]. Retrieved October 11, 2016, from http://osvita.mediasapiens.ua/ media_law/law/scho_vidbuvaetsya_na_skhodi_ukraini_sche_raz_pro_terminologiyu/ [in Ukrainian].

9. Smola, L. Ye. (2015). Aspekty neliniinoi viiny v konteksti ukrainsko-rosiiskoho konfliktu na Donbasi [The aspects of nonlinear warfare in the context of Ukrainian-Russian conflict in Donbas]. Journal of Naukovyy chasopys NPU imeni M. P. Drahomanova. Seriia 22: Politychni nauky ta metodyka vykladannia sotsialno-politychnykh dystsyplin - The scientific journal of the Dragomanov National Pedagogical University. Series 22: Political science and methods of teaching social and political subjects, 16, 74-78 [in Ukrainian].

10. Harris, R. (2003). Psiholohiia massovikh kommunikatsii [Psychology of Mass Communication]. Sankt-Peterburg: Russia: Praym-Evroznak [in Russian].

11. Cohen, B. (1963). The Press and Foreign Policy. Princeton: Princeton University Press [in English].

\section{Исследована медийная политика террористических группи-} ровок, которая стала одним из инструментов ведения гибридной войны в Украине. Выделены тематические группы новостей, которые составляют привычный порядок дня сепаратистских новостных сайтов: гиперболизация экономических, политических, социальных и других проблем в Украине; “кровавые преступления» украинских «карателей"; деморализация Вооруженных сил Украины (суициды, низкий уровень воинской дисциплины); “достижения» самопровозглашенных республик, подвиги ополченцев; сообще-

ния об успехах России в экономике, внешней политике; критика США; негатив об отношении в Украине к бойцам АТО и волонтерам; негатив об отношении в Украине к внутренним переселенцам, русскому языку. Обоснована необходимость и предложены направления информационно-разъяснительной работы среди населения, воспитательных, просветительских мероприятий, которые бы объединяли общество вокруг идеи украинской государственности.

Ключевые слова: информационная война; новости; манипуляция; медиа; гиперболизация; украинское общество; украинская государственность. 
This article deals with the media policy of terrorist groups, that has become one of the tools of the hybrid warfare in Ukraine.

The separatist's sites rusvesna.su, novorosinform.org, http://antifashist.com and www.dnr-news.com are investigated. The news groups that make up the usual order of the day of the separatist news sites are emphasized: exaggeration of the economic, political, social and other problems in Ukraine; 'Bloody crimes' of Ukrainian 'chasteners'; demoralization of the Armed

Forces of Ukraine (suicides, low level of military discipline); the achievements of self-proclaimed republics, separatist's feats; reports on Russian successes in the economy and foreign policy; US criticism; negative attitude to soldiers and volunteers in Ukraine; negative attitude to the internally displaced people in Ukraine, Russian language, and Christian values. Separatist news sites adhere to common priorities in the selection of topics to cover, some events become more publicized than others. In addition, these sites tend to produce numerous fake news, disseminating completely artificial and non-existent problems. Journalists of separatist's media are very selective in the picking of events, justifying government policy of the selfproclaimed republics. The separatists openly and aggressively express the Russian political narrative: Russian World, Russian values, Russian soul. The basic principles of journalistic ethics are violated. There is no balance of opinion, the facts are not separated from comments. The activities of separatist's media are dangerous because they may influence not only the mind but also the behavior of recipients.

The Ukrainian society has to improve the culture of news consumption, which is the ability to analytically select, check, compare, evaluate, and decode them. Every citizen has to learn how to interpret, analyze, and evaluate texts, understand their essence, targeted focus, goals, reveal hidden value, and the impact of individual information.

Keywords: information warfare; news; manipulation; media; exaggeration; Ukrainian society; Ukrainian state. 